\title{
委員会報告
}

\section{“鋼構造物設計指針”の背景と展望 \\ BACKGROUNDS OF “DESIGN CODE FOR STEEL STRUCTURES” AND PROSPECTS OF ITS USE AND DEVELOPMENT}

\author{
鋼構造委員会 鋼構造物設計指針小委員会 \\ By Subcommittee on Design Code for Steel Structures, Committee on Steel Structures
}

\section{1. 小委員会設立の背量と経緯}

土木工学分野における鋼構造物の設計は橋梁に関する 技術を中心に発達してきており，現在でも橋梁に関する 基準（道路橋示方書 ${ }^{1)}$ ，国鉄建造物設計標準 ${ }^{2)}$ ）が，土 木鋼構造物の，わが国では最も完成度の高い規範である ことは論をまたないであろう.しかしその一方で, 水門, 水圧鉄管, 石油・ガスのホルダー, あるいは原子力発電 所の容器や設備などのエネルギー関連施設, 海岸・海洋 構造物, さらにはアンテナ, 鉄塔等の情報通信関連の施 設などきわめて多種多様な構造物の設計も, 従来から土 木技術者の守備範囲となってきた実績がある．近年こう した橋梁以外の構造物の設計に対する需要が相対的に大 きくなりつつあり, それに伴って, 広い範囲の鋼構造物 に適用可能な設計指針の整備を求める要望の声が高まっ てきた.

古い時代には構造分野の技術者の数が少なく, 専門の 分化も少なかったため, 異種の構造物に対する設計基準 も同じ技術者集団によって作られてきた。これらの設計 基準では, 当然のことながら構造物の性格によらず不変 の部分には同じ条項が用いられ, 性格によって変わる部 分には異なった規定が用いられてきた．構造物によって は使用目的（主要な荷重）や形状が異なるだけでなく， 発注者の様態, 設計上の安全性確保の考え方, 施工・供 用環境, 求められる（と思われる）利用年数などにおい て, さまざまな, 微妙な相違があると思われる. よく知 られている例をとれば, 道路橋示方書ではJIS 規格の 鋼材の降伏点強度に約 1.7 の安全率を見込んで基本とな る許容応力度を定めているのに対し, 建築物ではこの安

Keywords: steel structures, design code, limit stdtes design
全率が約 1.5 となっている.この相違は, 荷重の違い, 構造形式の違い，発注者の性格の違いなど，さまざまな 要因を反映したものとして説明されよう.

多くの構造物について，それぞれ独自に設計基準が整 備されているが, これらの基準は特定の構造物を対象と している.現在ではそのどれにも当てはまらない構造物 の設計をする必要も生じている.これらの基準を部分的 に用いようとしても，基準間で相矛盾する条項も多く， 困難を伴うことが多い，最も適用範曲の広いのは橋梁の 設計基準であろうが，橋梁を対象とすることを前提とし て発展してきた技術を，そのままの形で他の構造物に適 用しようとすることには無理がある. 他方，すでに日本 建築学会では, 対象を特定していない, 汎用的な鋼構造 基準である「鋼構造設計規準」3)をはじめとするいくつ かの基準類が整備されており，これらの基準と道路橋示 方書との間で，条項の選択に技術者が迷うことも少なく ないという報告を耳にすることもある．それゆえ，土木 学会としても，技術者向けに，ある程度の解説を含んで 教科書的性格をも備えた, 汎用鋼構造設計指針の整備を 早急に進めることが必要であるという認識が生まれ，そ こからこの小委員会の活動は出発している。この指針を 通して, 特定の構造物を対象とする設計基準間の比較を 容易にし，異なった技術者集団間の意思の疎通の不足に よる不必要な条項間の相違を少なくするのに役立つので はないかとの考えも，小委員会活動の動機の 1 つである.

構造物によっては, 必ずしも設計, 施工が土木技術者 の手になるとは限らない，土木と建築のいずれの分野に 分類されるか判然としないものも多いし，海洋構造物の 中でも造船関係の技術者の手になる部分も多い，送電鉄 塔の設計は大部分が電気技術者の仕事になっているのが 
現状といえる. 今後さらに鋼構造設計への要求が多様化 し, どの分野の技術者の守備範囲となるかが明確に判定 できないものもいろいろと出てくることが予想される. そうした状況認識に基づけば, 多様な設計需要に, 柔軟 に対応し得るよう，土木技術者の啓蒙を進めるとともに， 利用可能な基準を整えて，技術の幅を広げていくことの 必要性は明らかである. 公共機関以外の主体によって発 注される構造物については, 他の工学分野との競合関係 が予想される. 設計技術者に「柔軟性」,「幅」が求めら れるといった, 先に述べたことに加えて, 安全性とコス トの関係について，これまで以上に厳しい見方が生まれ てくることも考えられるので, 各種の基準を改めて統一 的に見直すという発想もあってよいであろう.

構造物の設計基準を許容応力度法から限界状態設計法 に変更するのが世界のすう勢になっている．信頼性理論 の発展をもとに, 安全性に直接関連する荷重や強度の条 項の見なおしも同時に行われている. 許容応力度法の書 式は，いわゆる限界状態設計法の書式と異なるものの, 鋼構造物の基準に限れば, 内容的には許容応力度法は限 界状態設計法と本質的に変わることはないと考えてよ ( $)^{4)}$. しかし, 許容応力度法の書式は, その本質が限界 状態設計法と同じであると理解するには必ずしも適切と はいえない, 将来の展望を考えると, 許容応力度法の書 式で書かれている基準を, 限界状態設計法の書式で統一 的にまとめ直すのも有意義であろうとの考えも，本指針 作成の動機の 1 つである.

当小委員会は, 西野文雄東京大学教授を委員長として, 昭和 59 年度より発足, 上記の主旨に基づき, 汎用的な 鋼構造物の設計指針の作成を目標に作業を進めてきた。 発足に先立って, 土木学会誌 58 年 10,11 月号誌上で委 員公募を行い，問い合せに応じて主旨説明を行った．発 足時の委員の総数は委員長を含めて 44 名 (うち大学関 係者 25 名, 官公庁, 電力関係者 4 名, 鉄鋼, 重工, 橋 梁の企業関係者 15 名）である. 審議の進行に伴い, 執 筆上の必要に応じて委員を追加し，また多少の委員の交 代もあり, 62 年 6 月現在では委員数 58 名 (大学等 33 名, 官公庁等 4 名，鉄鋼等 21 名）となっている.

第 1 回小委員会 (59 年 4 月) の席上,

(1) 土木学会コンクリート標準示方書, 建築学会鋼構 造設計規準等をモデルに，対象を特定しない汎用鋼 構造物設計指針を作成する.

(2) とりあえず，骨組構造物の設計を念頭におく。

(3) 内容的には，既存の基準類との間に矛盾が生じな いようにし, 条文化されているものの精選, 取捨選 択から作業を始める.

(4) ただし, 既存の設計基準の枠組みにはこだわらず, 目次の構成等には独自の方針を打出す.
(5) 大学等の研究機関で集積されている成果を, 既存 の設計基準に先立って条文の形で取り入れるモデル コードとしての機能をもつことも目標とする.

(6) 大学鎆構造教育の副教材として, 利用可能な成果 物となることも目標とする.

(7) 条文作成にあたっては, 極力限界状態設計法の書 式を用いる.

等の基本方針が定められ, 長谷川彰夫東京大学助教授(現 在アジア工科大学に出向中）を幹事長とする幹事会が具 体的な内容の執筆にあたることとなった.

以後, 3 年間にわたり, 毎年春に行われる構造工学シ ンポジウムの時期と秋の学会全国大会の時期を利用し て,小委員会を開催,都合 62 年 4 月時点で 7 回を数えた. 小委員会の間の各半年間に, 多いときで 6 回の幹事会を もつなど, 幹事会の開催回数は 24 回にのぼっている. 毎回の小委員会ごとに指針原案を改訂して提出したた め, 原案は第 6 次案まで改編されてきた。また，小委員 会の時間内，委員の範囲内での検討にとどまらず， 59 年 12 月には指針案の枠組みや, 内容の改訂の方向に関 して委員会内部のアンケート調査を行い,この結果をも とに, 60 年 4 月の第 3 回小委員会以降は, 各地区ごと に地区作業班（北海道・東北・中部・関西・九州）を設 置, 幹事会の原案作成作業に並行して, 今後取り入れる べき内容の検討等をそれぞれ独自に進めた．また 61 年 4 月の第 5 回小委員会の後に, その時点での原案（第 4 次案）を各大学, 企業の鋼構造担当者の方々に広く送付, 内容に対する意見照会を行った．このほかにも，委員相 互の文書による意見のやりとりを随時行い, 討議時間の 不足に対する補足の一助とした。

3 年間の作業の過程で, さまざまな検討の機会をもつ ことができたが, この結果, 当初に定めた方針にも少な からず追加，変更が行われた．その内容の概略は，

(2) 一(2)' 骨組構造物にとどまらず，より広い範囲の 構造物を対象とする。

（8）橋梁色を極力薄くする．橋梁では用いられること の少ない材料や接合方法をも利用できるような方向 とするが，条文と並んで解説の中での紹介を多く用 いる.

(9) 原則的に国内の基準を精選・取捨選択の対象とす る. また第 1 版の内容には研究成果を盛り込む形で の独自の条項作りは原則として行わない.

(10)指針案の枠組みの作成にあたっては，計算機利用 を前提とした構成に配慮する。

といった形にまとめられる.

62 年 4 月にまとめられた指針の最終原案の目次を表 -1に示す. 当初, (2)の方針により, 第 1 章から 11 章 に該当する部分までを指針の原案としていたが，上記の 
表一1 各童のタイトル

\begin{tabular}{|c|c|}
\hline \multicolumn{2}{|r|}{ PART A 一般構造物 } \\
\hline 第 1 章 & 則 \\
\hline 第 2 章 & 材 \\
\hline 第 3 章 & 荷 \\
\hline 第 4 章 & 構 造解析 \\
\hline 第 5 章 & 材料の強度 \\
\hline 第 6 章 & 荷重の組合せと安全率 \\
\hline 第 7 章 & 限界状態の照查 \\
\hline 第 8 章 & 部材に関する一般事項 \\
\hline 第 9 章 & 連結に関する一般事項 \\
\hline 第 10 章 & 骨組構造物に関する一般事項 \\
\hline 第 11 章 & 薄板構造物に関する一般事項 \\
\hline 付録一 1 & 土木鋼構造物の安全性確保について \\
\hline 付録一2 & 限界状態の照査における \\
\hline & 断面力表示と応力表示 \\
\hline & PART B 特定構造物 \\
\hline 第 12 章 & 複合構造物 \\
\hline 第 13 章 & 管路および曲面構造物 \\
\hline 第 14 章 & ケーブル構造物 \\
\hline 第 15 章 & <い·矢板構造物 \\
\hline 第 16 章 & 海洋構造物 \\
\hline 第 17 章 & 軽量形鋼構造物 \\
\hline
\end{tabular}

(2)への変更により，12 章以下の部分を追加した．ただ し， 11 章以前と 12 章以後の構造物とでは, 既存の基準 の完成度も, 一般土木技術者の理解, 経験も著しく異 なるため，作成方針を違えることとした．PART A, PART B という分類が行われているのはそのせいであ る. 各章の内容は次節で述べるが, 前半の PART A は 力学規定を中心とした, 汎用の鋼構造物設計基準であ り，(1)で述べた方針とも合致するものである．後半の PART B は, 土木工学分野の中でも比較的限られた分 野で行われている設計に対し，一般技術者の理解を助け るための “手引き”としての性格をもつと同時に，各種 の構造物に対する基準を集合することによって，基本的 な考え方の相違を明らかにしようとするものである．後 半の部分については, 教科書的性格を重んじている半面, 必ずしも条項に沿って直接設計ができることには重きを おいていない。また，各種構造物の設計慣行に準扰する ことを原則としたため, 前半部，あるいは後半の他の章 との整合性には必ずしも厳密な注意は払わなかった。特 に 16 章の海洋構造物では，現状の設計の大部分が海外 の基準に準拠していることから,(9)の原則にかかわらず, 国内の基準を用いていない.

最終的に, PART A, PART B は分冊として刊行す ることとした．PART A，B はいずれも一般技術者の参 考資料としての便を第一の目的とするものではあるが, 特に PART A は大学鋼構造教育の副読本としての性格 をも期待し得るものであり，教材として使用する際の便 を考え，後半と分離した．同時にPART A は，鋼構造
物の限界状態設計法のモデルコードとしてはわが国で公 表される最初のものであり, 今後道路橋示方書その他の 基準類がこうした方向に改訂されることを先取りした教 材ともなっている．さらに，この指針は法的な拘束力と は無関係な, 土木学会独自の成果物であり, 今後学会内 部の研究成果を盛り込んだ形で自由に改訂し得る受け皿 としての機能も期待できるものであるといえる．この意 味で, 今後ともモデル・コードとしての性格をもち, 他 の基準に先立って研究成果を取り入れる形で発展するこ とを期待する.

\section{2. 各章の内容と特徴}

表一1の各章につき，作成方針，作成経過，内容，特 徵等を概説する。

\section{（1）第 1 章から第 7 章まで，および付録}

鋼構造一般の設計に適用可能な指針の基本的な部分を 盛り込むことを目標とし，原案を作成した ${ }^{5}$. 内容は, 道路橋示方書を中心に，内外の設計基準を参考にしてい るが, 前述のように, 小委員会, 幹事会での審議, 地区 作業班の検討結果，アンケートによる意見照会等を通じ て，充実および一般化をはかった。これらの章の範囲で は, 既存の, 許容応力度法で書かれた設計基準の内容を, 限界状態設計法の観点から見直し, 再構成する形をとっ ている. 鋼構造の場合には, 従来の基準の実質的内容は, 終局限界状態を考慮した設計法と理解できるため, 許容 応力度の概念から，限界強度と安全率の概念を分離する ことにより，限界状態設計法としての表現に変換するこ とがさほざ困難を伴わずに実行し得る4).こうした状況 は，指針のまえがきにおいても触れている．ここでの安 全率は，設計荷重を超える荷重の作用，強度を中心とす る設計限界値を下回る限界値の存在に対するものではな く，それ以外の要因に対するものであり，人的過誤のよ うに設計で考慮されない要因に限定して対処する目的の ものである. 1 つの荷重状態, 限界状態に対して, 安全 率が基準によって異なるのは不自然であるという意見も あったが，ここでは特に 1 つの值となるようには修正せ ず，許容応力度から分離された值をそのまま用いた。第 2 版以降で検討すべき課題の 1 つである. また, 個々の 条項にその条項解説を追加するという形式だけでは，鎆 構造物の安全性確保のために基本的に考虑すべきことが らや，限界状態設計法の長所と短所といった点を理解す るうえで限界があると考えられたため，指針の基本理念 を明確にすることと，教科書としての使用上の便に配慮 して，付録に解説を補足している．以下，内容の概略と 特徵を章立てに沿って記述する。

1）第 1 章 総 則

鋼構造物一般の設計に適用可能な指針であり，設計思 
想が限界状態設計法に基づいていることを適用範囲の箇 所に明示したうえで，考慮すべき設計の原則について言 及している，さらに，準拠すべき設計基準が存在する場 合には，そこの規定が優先することを喚起する意味で， 「関連する基準」に代表的な設計基準類を列挙している. 本指針では, SI 単位系への単位表示の移行を配慮し，

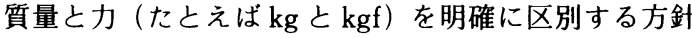
を採用している.

\section{2）第 2 章材料}

まず，条文において，道路橋・鉄道橋・建築物で通常 使用される鋼材を JIS 規格を参考に記述し，次に，解 説において，代表的な鋼構造物において使用されている 材料を例示している. ステンレス鋼板やアルミニウム合 金にも言及している.

\section{3）第3章 荷}

本指針で対象とする構造物は多岐にわたっているの で，考慮すべき荷重を一律に特定することは適切でない との判断から，設計荷重の决定を責任技術者の裁量に委 ねるとともに，代表的な構造物において考虑されている 荷重を解説に例示することとした．解説文中では，教科 書としての性格にも配虑して, 構造物の性格が, 支配的 な荷重の力学的・統計的性質に大きく依存することや, 荷重に対する 1 つの考え方として, 通常の設計荷重とし ては安全性確保のために，考えられる最大値など，十分 大きな值が与えられていることなどについて触れてい る。

\section{4）第 4 章 構造解析}

構造解析にあたっては, 微小変位のはり理論あるいは 板款理論を用いて線形解析を行うことを前提としてい る、ただし，責任技術者が必要と認める場合には有限変 位解析・非弾性解析等の非線形構造解析を行うこととし ている。また，電算機を使用して構造解析を行う場合に は, 構造モデル, 計算目的, 計算条件, 計算手法などの 適合性に十分配慮すべきことを解説文中で述べている. さらに, 特別な考慮を必要とする非線形構造解析の具体 例を列挙している。

\section{5）第 5 章 材料の強度}

本来ならば，「材料固有の強度」のみを提示し，これ と正確に計算された荷重効果（たとえば軸圧縮力）との 比較によって安全性の照査がなされることが望ましい が，設計者に非線形解析を委ねる繁雑さを避ける意味か ら，材料強度の側に非線形性の影響を入れて評価してい る.すなわち，本指針では微小変位のはり理論あるいは 板殻理論を用いた線形構造解析をもとに，7章の限界状 態の照査が行われることを前提に, 対応する強度を適宜 適切な形で示している. 解説文中では, 教科書としての 性格にも配虑し, 各種の強度の意味とその背景について
述べ, 定められた強度が供用期間中における最低保証値 であることに触れている.

\section{6）第 6 章 荷重の組合せと安全率}

対象とする構造物によって，考慮すべき荷重の種類と その構造設計が異なることを精神規定として定めてい る. 解説では，代表的な構造物について，荷重の組合せ と安全率を例示している.そこでは，終局限界状態を対 象とし, 板厚が $40 \mathrm{~mm}$ 以下の構造用鋼材の降伏点強度 に対する許容応力度を参考に，許容応力度の割増し率を 安全率に対する低減率と解釈して, 各構造物の荷重の組 合せと安全率を示している. 従来から用いられている基 準の内容に変更を加えないことを原則としたために，安 全率, 組み合せる荷重の值の大きさに変更を加えていな いが, 今後の研究の成果を期待する章であり, 第 2 版以 降で検討すべき課題の 1 つである.

\section{7）第 7 童 限界状態の照査}

各基準では，原則として設計で考虑すべき限界状態の すべてを照査する条項を含めているが，考慮すべき限界 状態は構造物によって多少異なるため, 基準間には照査 すべき限界状態に相違がある，本指針では，䤡構造物の 設計で照査を要する限界状態として, 終局限界状態・使 用限界状態 - 疲労限界状態の 3 種類が必要であると考 え，それぞれの限界状態を明確にしたうえで設計を行う ことを原則としている. 限界状態の照査式そのものは, 道路橋示方書 ${ }^{1}$ の規定と本質的に異なる点はない. 特徴 としては, 限界状態を明確に表現するためと設計の幅と 選択枝を広げるため, 終局限界状態の照査式の限界量の 表現に原則として断面力を用いた点が挙げられる.

8）付録一1 土木罁搆造物の安全性確保について

この部分は, PART A の 3 章, 6 章, あるいは 7 章に おいて触れられている, 具体的な数値の決め方, 安全率 のとり方，限界状態のとらえ方などについての説明の補 足となっている. 指針としての形式の範囲で解説し得る 事項に加え, 安全性確保に対する基本的考え方について の利用者の理解を助ける目的で加えた.

「限界状態設計法」という用語にも，「限界状態の定義 を明確にして用いる設計法」あるいは「可能なかぎり確 率論を用いて行う設計法」など，さまざまな理解がある こと，限界状態を終局と使用に区別するだけでなく，同 じ終局限界状態の中にも, 性格を異にするものが多く, 指針の中で対比していくことが可能である. 確率論の導 入とも矛盾しないことを考慮して ${ }^{4)}$, 本指針では, 従来 から採用されてきた所定耐用期間中に作用する最大値, もしくはそれに確率的な意味で相当する荷重, すなわち 所定耐用期間中に超過する確率が十分に小さくなるよう に選んだ值を設計荷重とし，そこに係数をかける必要性 を認めなかった．地震や風荷重のように必ずしも超過確 
率が十分小さくなる条件を満たしていない荷重も存在す るが，これらは経済性をもとに值が決められたものであ ろうと判断し，本指針では，このような荷重に対しても 従来からの值を設計荷重としている．同様に強度を中心 とする限界値としても，従来から採用されてきた値，す なわち非超過確率が十分に小さくなるように選んだ值を そのまま設計に用いる限界値に選んだ。このように荷重 の超過, 限界値の不足に対する安全性は, 荷重の選択, 限界值の選択で確保したうえで,これら以外の要因で構 造物の安全性に影響する要因があることに配慮して，さ らに積極的に「一定の余裕としての安全率」を確保すべ きであることを述べている4).

9）付録一2 限界状態の照查における断面力表示と 応力表示

ここは 7 章の補足事項として位置づけられる．7章に おける安全率の分離, 断面力表示の採用という形式は, 限界状態の内容をより忠実に照査式上に表現するという 目的に沿ったものであるが, 半面で条項の煩雑化が小委 員会や意見照会の場で指摘されてきた. 形式の比較を行 うほか, 指針の用途 (実設計か教科書か), 将来の発展 方向，適用対象の別による違い（土木と建築の対比，鋼 とコンクリートの対比)等のことまで考察を述べている.

（2）第 8 章 部材に関する一般事項および第 9 章 連結に関する一般事項

部材および連結に関する構造細目規定をまとめたもの である. 内容的には道路橋示方書を基本にしている部分 が多いが，指針の用途に鑑み，設計に用い得る自由度が 広げられるよう配虑した。板厚制限等を設計者の裁量に 委ねるなざ，精神規定化（解説で条項を例示）させた部 分や, 連結で普通ボルト等の使用を認めた部分があり, その他各種基準等から, 耐圧部材, 応力集中, 腐食代, 湾曲部材, 風による振動を受ける部材といった項目を適 宜追加した.8章については, 骨組部材のほかに板も加 え，鋼管を独立させて，7 章の限界状態の配列に合わせ た構成とした。

\section{（3）第 10 章 骨組構造物に関する一般事項}

第 9 章までの規定により設計される部材要素から構成 される骨組構造物について, 構造全体に対する注意事項 を述べた章である．設計対象として想定しているのは， トラス，ラーメン，アーチが中心である．鋼構造物全般 を対象とするため, 構造形式別の縦割りの記述を改め, 各種の項目に分けて，一般論を述べた後に形式別に注意 事項を記述するようにした．条文に取り上げた内容は， 部材の有効座屈長, 2 次応力を配虑した断面の構成, 骨 組構造の特徴と断面力の扱い方, 全体座屈の照查, たわ みとそり, 連結と格点構造, ダイヤフラムなどによる補 剖, 平面骨組構造解析の前提となる横方向への拘束, 支
承や下部構造としての留意点である．またやや特殊にな るが, 积長のトラス構造も, 建築学会の基準 ${ }^{3}$ や電気学 会の送電鉄塔の基準 ${ }^{6}$ をもとに取り入れた.

\section{（4）第 11 章 薄板構造物に関する一般事項}

プレートガーダー，鋼床版のように力学的な役割分担 が明らかな板要素の集合体として全体構造が定義できる 構造物を扱った章である. 前半の各節で, 平板要素に関 する力学条項と解析方法について, 適用範囲之解析方法 全般, 無補剛板の限界状態の照査法と平板の具体的な解 析手法, 有効幅の算出方法, 補剛板の限界状態の照查法 と補剛法に分けて規定している. 後半では, 連結部, 隅 角部, 荷重集中点, 全体構造に対する一般事項と, 薄板 構造物全体の設計に関する注意事項を示している，条項 部分は本指針のために新たに作成したものと道路橋示方 書 ${ }^{1)}$ に準拠したものとがあり, 解説には, 国鉄建造物設 計標準 $(\text { 土木学会 })^{2)}$, その他から多数引用している.

\section{（5）第 12 章 複合構造物}

ここからPART B に入る.ここで扱ったのは「合成 げた」,「鋼とコンクリートとの合成版」，「鉄骨鉄筋コン クリート構造物」,「鋼管コンクリート構造物」の 4 種類 であり, それぞれ, 各構造物ごとの既存の基準・指針類 や設計例に準拠しつつ, 限界状態設計法としての性格を もたせた条文としている．原則として各節がそれぞれに 独立し，完結した内容となるようにし，また，特に橋梁 色の強い用語や表現を避けている.「合成げた」につい ては，多くを道路橋示方書 ${ }^{1}$ に準拠しながらも，橋梁以 外のけたへの利用に配虑した内容とした.「鋼とコンク リートとの合成版」には，参照すべき基準類が未整備な ため，道路橋で使用頻度の高い構造の設計例を参考に条 項を作成したが，統一された具体的基準とすることは難 しく，精神論・一般論を中心とした、「鉄骨鉄筋コンク リート構造物」でも各種の基準類を参照しているが, 最 も多く用いたのは本四公団制定の基準》である.「鋼管 コンクリート構造物」では, 主に建築学会の基準8 を参 照し, 被覆形, 充填形, 充媜被覆形の 3 種のものについ てまとめた。

\section{（6）第 13 章 管路および曲面楎造物}

「管路構造物」,「水門屝」,「貯槽」から構成されており, 章内における目次構成の統一をはかったが, 内容的には 各節は独立して,それぞれに完結している.「管路構造物」 では, 石油パイプライン, 水圧鉄管, 水管橋を対象とし, 露出管・埋設管の場合について, 応力算定式を揭げて, 座屈・地震時を含む限界状態の照査法を示した。「水門 扉」では，主として水門鉄管技術基準帛に沿って設計に おける基本的事項を述べているが，構造解析に関して， 留意点の指摘を加えている.「貯槽」では多種多様な容 器構造物の中から, 地上式低温貯槽および地上式貯油槽 
に重点を置いて，特に耐震設計を詳細に述べている．危 険物の貯蔵施設については法的規制が㛜しいこと, 降伏 点以外に, 引張強さに対しても限界状態照査を行うこと などがこの節の特徴といえよう．この章では各節とも極 力説明図を入れて, 利用者の理解の一助としている.

\section{（7）第 14 章 ケーブル構造物}

吊橋, 斜張橋のような, ある程度確立された分野に限 らない, 一般形式としてのケーブル構造物を適用範囲と して, 道路橋示方書 ${ }^{1)}$, 建築構造ケーブル設計施工指

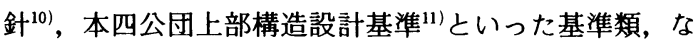
らびにいくつかの設計例を基本として構成している. 内 容の構成は「適用範囲」,「ケーブル部材」,「支持構造部 材」, 「荷重」,「構造解析」, 「限界状態の照査」,「構造設 計」と,設計に必要な事項を体系的に網羅したものになっ ている. 個々の条項については広く認められる一般的な 設計式として盛り込める程度の, 十分な解析がなされて いないものも多く（たとえばケーブル部材の疲労特性, ケーブル曲線部や定着部の応力分布や経時効果, ケーブ ル構造全体の振動特性等), 既往の規定や設計例の解説 によって, 設計上留意すべき事項を記述していく方針を とった. 特に構造設計の節では多くの留意事項を, 各基 準，設計例の間で矛盾なくまとめた．説明的図表を多く したのも前章と同様である. 原則とする構造解析の特殊 性 (有限変位弾性解析), 限界状態など, PART A の設 計と対比してみるのも興味深いと思われる.

\section{（8）第 15 章 くい・矢板構造物}

鋼を用いた基礎構造として一般性の高い「くい・矢板 構造物」を対象とした。この章も，専用基準を用いる前 の手引書としての性格を重視し, 設計の流れを示すフ ローチャート, 説明的図表を多くするよう努めた. 基本 となる基準間に多少精粗の差がある場合も, 現時点で統 合，選択することを避け，併記するのみならず，比較表 等を多く用いるようにした。 また，限界状態設計法とし ての性格をもたせるため, 断面力表示を採用した.「く いの設計」においては, 道路橋示方書の下部構造編 ${ }^{12)}$ と 港湾の施設の技術上の基準 ${ }^{13)}$ に主として準拠しており, また，「矢板壁の設計」では，自立式，控え式，切梁式 の 3 種を対象として基準類を参照した.この指針の他の 構造物と異なり，この章の規定は構造物にかかる荷重の 算定に重要な部分が多く, 限界状態は比較的単純である. こうした点も比較対照してみることができるであろう.

\section{（9）第 16 章 海洋構造物}

土木学会, 建築学会の基準の普及があまり進んでおら ず, 国外の API (米) ${ }^{14)}, \operatorname{DNV~(ノルウェー~}{ }^{15)}$ の基準 による実績が多いため，これらを主として用い，国内の 基準は折に触れて紹介するという構成とした。記述の対 象としたのは接地式海洋構造物であり, 上部構造につい
ては鋼管部材等により構成される骨組, 基礎構造につい てはくい基礎, 重力式基礎である. 手引書としての性格 を重視して, 説明や図表を多く加え, さらに基礎の部分 についても詳しく記述したため,この指針中でも最も分 量の多い章となった. PART B の他の章と同様, この 章だけで独立して海洋構造物の設計の概要が理解できる ようになっている.上部構造では水圧に対する設計, 波 力による疲労, 格点部の設計に特徴があり, 下部では土 質定数の算定に多くの記述を費やしている. また，上部 構造では DNVの「準確率論的限界状態設計法」として 知られる方法がかなり一般的となっており，それに準拠 した部分も多いが，極力本指針の限界状態設計法の書式 に合うよう書直しに配虑した。しかし従来から用いられ ている許容応力度法と DNV の基準の間には基本的な設 計思想に多少の差異があるため, 同じ限界状態設計法の 書式で書かれているものの, 他の章の条項との間に相違 がみられる。

\section{（10）第17章 軽皇形銅構造物}

PART B の他の章と異なり, 構造物を構成する部材 について述べているが，これまで比較的土木技術者に馴 染みの薄かった軽量形鋼部材についての認識を広める意 味で，章を加えた．本来の主旨は，軽量形鋼という薄板 部材を用いた構造物において，熱間圧延鋼材を用いる場 合と特に異なる点, 注意を要する点についての記述を行 うことであるが，橋梁床版の埋め殺し型枠として用いら れるデッキプレートなどの, 軽量形䤡以外の薄板部材に も適用可能なように記述するよう努めた。案の作成にあ たっては建築学会の軽量形鎆構造設計施工指針 ${ }^{16)}$ を参照 して幹事会で原案を作成後, 各委員に対する意見照会に より改善を行った。ねじれや局部変形の影響, せん断遅 れの影響等を軸とした内容となっている.

\section{3. 今後の課題}

第 1 版の段階では，既存の基準の条項を精選・取捨選 択するという基本方針に従ったため，基本的な枠組みの 提示以外に, 委員会として独自の条項を盛り込むところ には至っていない，また参照した複数の基準に，異なっ た規定が定められているような場合，条文で一般的注意 を述べ，あるいは条件の選択を責任技術者の判断に委ね る，といった書き方をしたうえで，解説に各基準の規定 を示したところも多い.こうした方針は，第 1 段階とし ての成果が著しくバランスを失したものとならないよう な配慮によるものである.しかし，こうした活動の場を 通じて設計思想の整理をしていくことに対する期待も多 く, たとえばPART A の力学条項のところで, 独自の 理念をもった条文の記述を求める声や, 荷重, 安全率の 規定などで，実際に設計に使用できるよう，具体的な方 
向を示すことを求める声などは, 小委員会の審議の席で も，アンケート調査の場でも数多くみられた。「実用性」 と「教科書性」への要求を両立させることは必ずしも容 易ではないものの, これらのさまざまな要求を適切に, かつ実質的に取り入れて, 内容を改善させていくために も, 第 2 版に向けての計画づくりが早急に進められなけ ればならないと思われる。

ここではまず，第 1 版を作成してみての各章ごとの反 省点, 課題となる点等から挙げていくことにする. PART A は, ある程度は汎用基準としての実用性が必 要であるが, 条文間の整合性・適用範囲など検討すべき 点は多い. 用語の定義 1 つってみても, 橋梁で自明の ことが一般論として通用しないことはいくらでも挙げら れる.たとえば「主要部材と二次部材」,「連結, 継手, 接合, 格点 (隅角部)」といったことの区別,「部材」の 定義なよ゙，基準として完備するために必要と思われるの に，判断を下しきれなかったことも多い．このため総則 における用語の定義に詳細さが欠けた点もあろう. 5 章 で材料の強度, 6 章で荷重の組合せと安全率を与える必 要から，2 章で取り上げた材料の範囲が限定されたこと も，利用できる設計の選択枝を広げるという指針の理念 からすると不本意なことであった. 特殊な材料を取り込 むための方策も課題であろう. 荷重 (の組合せ), 安全 率といった問題では, その方面の専門家と鋼部材の専門 家が協議するなどして最新の調査・研究の成果を取り込 み, 対象構造物に応じた考え方を示すことが課題と思わ れる. 構造解析の章では計算機利用の高度化を踏まえて, より複雑な構造解析を設計者に委ねることの可能性が検 討されるべきであろう．これは，たとえば 10 章の骨組 構造の, 部材の有効座屈長の規定でも検討課題に挙げら れた点である. 5 章の材料の強度, 7 章の限界状態の照査, 以下 $8,9,10,11$ の各章は設計者の関心の対象となる 主要部分でもあり, 研究成果の受け具という当初の方針 を生かす意味でも, 次の段階で独自性のある条項案を入 れていく必要があるが, 特に板の限界状態のとらえ方と 設計法, 疲労限界状態の照査法等が課題として挙げられ る.このほか, リベット継手の扱い, 縦長トラスの扱い 等も課題となっている. 全体的にまだ残る橋梁色を薄め ていくのも課題といえよう.

PART B の各章に移ると，まず 12 章では，すでに土 木学会鋼・コンクリート合成構造小委員会で作成に着手 している「鋼・コンクリート合成構造設計のガイドライ ン」との関係をどのようにしていくかの問題がある. 12 章独自の問題としては, 混合構造物, あるいは, 非金属 系材料, アルミ合金等の非鉄金属材料を組合せに用いた 複合構造など適用範囲を広げていく可能性の検討, その 他新しい規定や研究成果の導入, 材料ごとの限界状態と
全体の限界状態の関係の明確化, 橋梁色, 建築色のある 表現の一般化などがある. 13 章でも, 研究成果の反映 による独自性のある基準の作成が課題だが, 今回記述し た範囲では, 板要素の限界状態の考え方と安全率の関係 づけ, 限界状態設計の考え方の浸透, 有限要素法による 構造解析の積極的導入等が指摘できる. また, 䝪槽の中 でサイロに関する記述をいま少し充実させたい，14 章 でも一般構造物を目標としながら, 橋梁色が残り, 一般 性と具体性に欠ける面が残っている。この章の役割は ケーブルを主要な構造要素とする構造物全体の設計法の 記述であるが, 部材（構造要素）としての個々のケーブ ルに関する研究がいま以上に一般化して, 7 章, 8 章の 中に一定の記述が載ることが望ましいであろう. その意 味で, 章単独としてのみならず, 他章にも影響を及ぼす ような発展が期待される. 15 章は, 従来鋼構造物とし ての性格を顧みられることの比較的少なかった基礎構造 物を他種のものと並列させたことに意義があると思われ るが, 今後とも, 構造技術者の観点から重点的に研究が 進められ，成果を取り入れた指針が作られることが期待 される.その際, 鋼と比較してはるかにばらつきの大き い土質の条件や施工の条件の問題を, 設計上どのように 圾うか, 基準として示す場合の書き方がどうなるか, な どの点が今後に残された重要課題と考えられる.16章 は他と異なって, 海外の基準中心に準拠して進めてきた ため, これらの基準に予想されている構造物の使用目的 が偏っているのみならず, 国内基準と基本的な考え方の 相違があり, 設計手法, 安全率の大きさなどの面で, 整 合性をとっていく必要があろう. 土質定数など, 日本近 海での適用に際し問題となる点は多々ある. 基礎の部分 では 15 章に述べたと同様の問題があると考えられる. 17 章では一応必要事項は網羅したものと考えられるが, 記述の独自性, 理解を助けるための図表や説明の整備等, 改善の余地はまだあるものと考えられる.

本指針作成の第一の意義は，すでに述べたことである が, 既存の設計基準を広い範囲の鋼構造物に適用可能な 形にまとめたことである. 次いで, 従来から用いられて きた許容応力度法による設計基準を, 内容の本質を変え ることなく限界状態設計法の書式に書き変えたことであ る.この書き変えによって基準の内容が変わることはな いが, 内容について誤解を受けやすい書式から, 内容が 理解しやすくなっている. 設計基準を限界状態設計法の 書式に改めるのが, 世界のすう勢となっているが, 一般 に限界状態設計法の書式に改めることと, 条項の内容の 変更とが同時に併行して行われることが多く, 設計に携 わる技術者の間に混乱を生じているのも事実である. 設 計基準の内容を変更するにあたって, まず現行の基準の 内容を正確に理解することが重要であるのは当然のこと 
である. 近年の設計に対する信頼性理論の成果を取り入 れ，限界状態設計法の書式で基準を整備するには，まず 現行の書式を内容を変更せず限界状態設計法の書式に改 め, ついで条項の内容を改訂する 2 段階のステップを踏 むことが, 混乱を避け, 基準を改訂する最良の方法では ないかとの考えにより本指針は作成されている.

既存の基準を 1 つにまとめ, 限界状態設計法の書式で 統一して書き表わしたことにより，各基準間の考え方の 混乱や，異なった鋼構造物に対する設計基準間での考え 方の相違が理解されやすくなったものと考えている. 今 後本指針も含め, 鋼構造物の設計基準を限界状態設計法 に変更し, 内容のより一層の改善をするにあたって, 今 回の指針がその出発点となるとともに大きな役割を果た すものと期待したい.

今までに蓄積された研究の成果のうち，いまだ設計基 準に反映されていないもの,さらには今後の研究成果を, 取り入れるに容易な容器を作るのも本指針作成の趣旨で ある. 限界状態設計法の書式で, 汎用的な鋼構造物の設 計指針を作成できたことは，この趣旨に沿うものと考え る. 本指針の第 2 版には，これらの成果を取り入れ，内 容的により充実したものとなることを期待したい.

これらのほかに, 全体的な反省点として, 記述が十分 に練られておらず, 理解しにくいところが残っている可 能性があること, SI 単位系の使用を時期尚早として見 送ったことなども併せて述べておく.

今後の展望として考えなければならないことは, 本文 の最初に述べた委員会設立の主旨に沿った形での第 2 版 を実現するための組織とスケジュールづくりが第一であ る. 同時に, 土木鋼構造の設計技術者のおかれている現 状と末来一一多様化と競争に象徵される一一認識を広 めるための地道な啓蒙活動であろう.

謝辞：本指針をとりまとめるに際し，委員会とし
て公式, 非公式に外部の方から多くのご指導, ご助言を 頂いた．深甚な謝意を表する次第である.

\section{考文 献}

1) 日本道路協会：道路橋示方書・同解説（I 共通編，II 鋼 橋編), 1980 年 2 月.

2）土木学会 : 国鉄建造物設計標準解説, 1983 年 4 月.

3）日本建築学会：鋼構造設計規準，1973 年 5 月.

4）西野文雄 - 佐藤尚次 - 長谷川彰夫：許容応力度法の内容 と問題点一限界状態設計法および安全性照查の観点から 見て一，橋梁と基砹，Vol.12, No. 12 およびVol.13, No. 1, 1983 年 12 月, 1984 年 1 月.

5）西野文雄 (代表者)：鋼橋および銅橋部材の非弾性不安定 挙動之設計基準に関する研究, 文部省科学研究費補助金 （総合研究 $\mathrm{A}$, 課題番号 57350028) 研究成果報告書, 1984 年 3 月.

6）電気学会：送電用支持物設計標準, 1983 年 4 月.

7）本州四国連絡橋公団：鉄骨鉄筋コンクリート構造設計指 針・同解説, 1977 年 8 月.

8）日本建築学会：鋼管コンクリート構造計算規準・同解説, 1980 年 2 月.

9）水門鉄管協会：水門鉄管技術基準，1981 年 11 月.

10）日本鋼構造協会：建築構造ケーブル設計施工指針・同解 説, JSSC, 1983 年 11 月.

11）本州四国連絡橋公団：上部構造設計基準 - 同解説, 1980 年 6 月.

12）日本道路協会：道路橋示方書 - 同解説（I 共通編，IV下 部構造編), 1980 年 5 月.

13）日本港湾協会：港湾の施設の技術上の基準・同解説, 1979 年 3 月.

14) American Petroleum Institute : API Recommended Practice for Planning, Designing and Constructing Fixed Offshore Platforms, 15th Ed., 1984.

15) Det Norske Veritas : Rule for the Design, Construction and Inspection of Offshore Structures, 1977.

16）日本建築学会：軽量形鋼構造設計施工指針 - 同解説, 1974 年 10 月.

(1987.6.29 - 受付) 